\title{
When antivaccine sentiment turned violent: the Montréal Vaccine Riot of 1885
}

— Cite as: CMAJ 2021 April 6;193:E490-2. doi: 10.1503/cmaj.202820

CMAJ Podcasts: author interview at www.cmaj.ca/lookup/doi/10.1503/cmaj.202820/tab-related-content

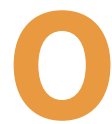

n Jan. 30, 2021, antivaccine protestors briefly disrupted efforts at Dodger Stadium to administer vaccinations against severe acute respiratory syndrome coronavirus 2 (SARSCoV-2), the virus that causes coronavirus disease 2019 (COVID-19). Other protestors have disrupted shopping centres to pro- test mask mandates, curfews and lockdowns that have been enacted to help slow spread of the virus, and at least 1 protest forced a lockdown at a hospital. ${ }^{1}$ In the last year, there has been large growth in antivaccine groups on social media. ${ }^{2}$ Similar protests against COVID-19 public health measures, some of which turned violent, have occurred in many cities in 2020 and 2021, often linked to partisan political divides. ${ }^{3,4}$ However, violent protests over vaccination campaigns are not unique to our time, as illustrated by the Montréal Vaccine Riot of 1885.

The last endemic case of smallpox in Canada occurred in 1946, but before

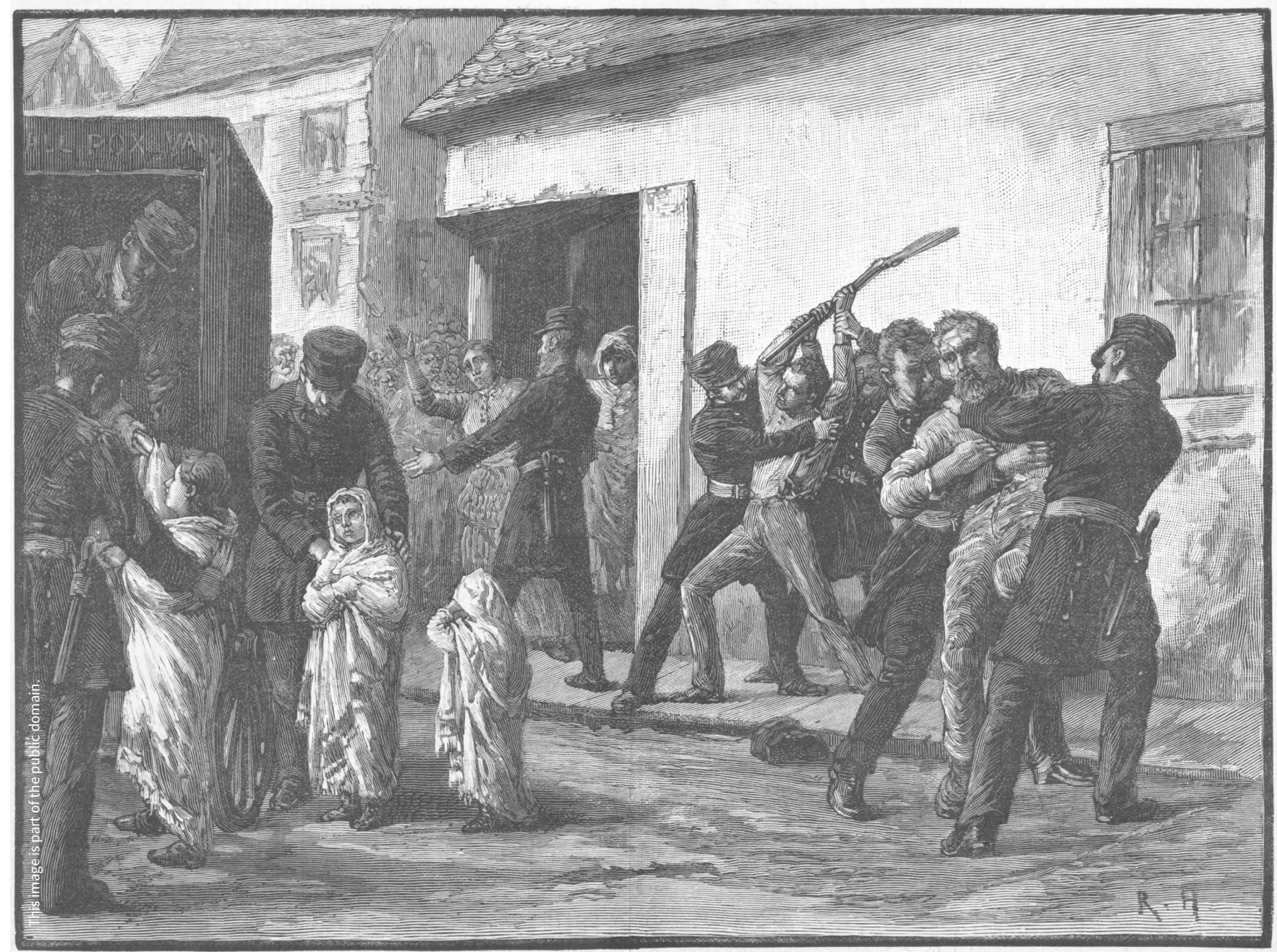

This drawing by Robert Harris is titled "Incident of the smallpox epidemic, Montréal.” It illustrates sanitary police removing patients from the public through the use of force, contemporary to the antivaccination riots of 1885 . 
widespread vaccination, smallpox outbreaks were common. Smallpox was a self-limiting, deadly disease caused by the variola major and variola minor viruses. It spread through respiratory droplets, and infection of the sebaceous glands produced pustules that would burst, leaving scar tissue pockmarks in $65 \%-80 \%$ of patients. The case fatality rate was about $15 \%$ in unvaccinated and unvariolated people who became sick with smallpox. ${ }^{5}$ Those who survived developed immunity.

In March 1885, a conductor of the Grand Trunk Railway arrived in Montréal carrying smallpox, which soon spread through the city. ${ }^{6}$ Subsequent vaccination efforts did not unfold smoothly. Several cases of erysipelas after vaccination, likely caused by unsanitary conditions, led health officials to believe that a bad batch of vaccines was being used. This led to a suspension of the vaccination program for 3 months, starting in May 1885. People opposed to the vaccination spread word that the smallpox vaccine was dangerous and pulled down warning signs that public health workers posted to the homes of people who were diagnosed with smallpox. In poor, predominantly French-speaking areas of the city, the disease flourished; contemporary Englishspeaking editorials blamed the living conditions of slums occupied by the poor, ignoring the uneven and often poor quality of the vaccination program. Over the summer, the epidemic became worse.

By Sept. 2, 1885, the Board of Health in Montréal believed that there were about 2000 cases of smallpox present in the city. By Sept. 28, some experts were estimating 4000 cases. By late September, sanitary police began to forcibly remove people from housing conditions that made isolation impossible, often using harsh tactics, isolating the poor from housing and social support. On Sept. 28, the Board of Health announced that vaccination was to be made compulsory. In response, a "howling mob" surrounded the East End Branch Health Office that evening and "wrecked" the building. ${ }^{6}$ Protestors were as concerned with matters of identity as with vaccination, shouting phrases like, "Hurrah for the French-Canadians; Montréal is no longer for the English nor Irish."”
Constables gathered, but were driven away by the mob. The crowd travelled through the city, smashing windows of pharmacies that sold vaccines and of the homes of health officers. Antivaccine protesters smashed all the windows in the Central Police Station. The Chief of Police was stabbed and stoned, though he survived. Rioters fired at police, and police escalated their tactics in an attempt to disperse the mob. They armed themselves with rifles and bayonets, firing above the heads of the crowd. Finally, they began clubbing the rioters, causing them to break into groups that continued the destruction of property, damaging various buildings.

The next day, officials worried that more violence would occur. Although the Board of Health was ambivalent about resorting to force, 1400 armed military men gathered at the city hall and patrolled the city. Sanitary police were issued revolvers. The Board of Health blamed the riots on lies told by vaccine opponents - that vaccine administrators would enter women's bedrooms and tie children down to be vaccinated. No further major violence occurred. Whether the display of force was effective, or the crowd had ceased interest in rioting, or simply was not organized, is unclear. For the most part, the riot resulted only in property damage.

In the 5-week period ending on Oct. 31, 1391, people died of smallpox in Montréal. Of those, 1286 were Frenchspeaking and about $90 \%$ were children under 10 years. Ultimately, the outbreak resulted in at least 19905 cases and 5964 deaths in the province of Quebec, with 3259 of these deaths in Montréal alone. ${ }^{8}$

The outcome of the riot was neither capitulation to the demands of antivaccine activists, nor a heavy-handed enforcement of policy. Rather, after this epidemic, the opposition to vaccination shifted to courtrooms and activist leagues. Ontario passed a Vaccination Act in 1887, which required that "parents must have their children vaccinated against smallpox within three months of birth and re-vaccinated when necessary every seven years." It allowed cities to issue vaccination orders in the event of a smallpox outbreak, and allowed school boards to demand that students provide a vaccination certificate. ${ }^{9}$ The AntiVaccination League of Canada emerged in 1900 , in part a reaction to the Vaccination Act, modelling its rhetoric and methods on British antivaccine groups. The British Anti-Compulsory Vaccination League had been founded in 1867, and in 1885 had its own (peaceful) march in Leicester with an estimated 100000 attendees. $^{10}$

Arguments from antivaccine campaigners invoked concerns about individual liberties and fears that the risk of vaccination might exceed the benefits. At the time, smallpox vaccines used lymph taken from cowpox pustules on cows or infected humans, and vaccines could become contaminated and cause secondary infections. ${ }^{11}$ Vaccine opponents wondered why some people became sick despite being vaccinated. ${ }^{12}$ Among physicians, theoretical questions swirled around how vaccination worked, and many wondered if cowpox, used to make vaccines, was caused by the same virus as smallpox. ${ }^{13}$

Notably for physicians today, it was not scientific uncertainty alone that allowed antivaccine campaigners to effectively push back against public health laws. In 1906, 2 decades after the Montréal riots, the Anti-Vaccination League of Canada succeeded in convincing the Toronto Department of Health to remove a vaccination requirement from schools. Antivaccine activists framed their opposition in terms of social class and personal autonomy. Alexander Ross, one of the founders of the League, wrote in 1888, "It is the poor wives and children of laboring men; it is the clerks in the stores and operatives in factories and workshops; it is the workingmen and women that are threatened and driven by the hirelings of the infamous compulsory vaccination law." ${ }^{14}$ Opposition to smallpox vaccination, whether expressed by angry crowds or constrained to courtrooms, communicated discomfort with a shift in power over a personal health decision.

Although smallpox was eventually eradicated, antivaccine sentiment was not. Recent surveys have shown that nearly a third of Canadians would be unwilling to take a vaccine against SARS-CoV-2. ${ }^{15}$ 
Today, just as in 1885 , many people see public health policies as another expression of society's power imbalances. If there is a lesson for doctors from the Montréal Vaccine Riot, it may be to respect the power of personal health decisions, and to remember that power has multiple forms of expression. For many, a personal health decision is something reached over time, often in the context of a trusted patientphysician relationship.

\section{Jonathan M. Berman PhD}

Department of Basic Science, New York Institute of Technology College of

Osteopathic Medicine at Arkansas State University, Jonesboro, Ark.

\section{References}

1. KOIN 6 news staff. ClarkCo: 'Anti-vax' protesters force lockdown at ClarkCo hospital. KOIN 6 News [Portland (OR)] 2021 Jan. 29. (accessed 2021 Feb. 20).

2. Burki T. The online anti-vaccine movement in the age of COVID-19. Lancet Digit Health 2020;2: e504-5.
3. Hapuhennedige S. Public health experts are learning from Canada's anti-mask protests. CMAJ 2020;192:E1274-5.

4. Hotez PJ. COVID19 meets the antivaccine movement. Microbes Infect 2020;22:162-4.

5. Gani R, Leach SJN. Transmission potential of smallpox in contemporary populations [published erratum in Nature 2002;415:1056]. Nature 2001;414:748-51.

6. A vaccination riot in Montreal. The Deseret News 1885 Oct. 2; By Telegraph:1(col 1).

7. Bliss M. Plague: a history of smallpox in Montreal. Toronto: HarperCollins; 1991.

8. MacDougall H. Be wise - immunize! Vaccination in Canada, 1798-1978. Can Pharm J 2007;140: S5-S7.

9. Arnup K. "Victims of vaccination?": Opposition to compulsory immunization in Ontario, 1900-90. Can Bull Med Hist 1992;9:159-76.

10. Wolfe RM, Sharp LKJB. Anti-vaccinationists past and present. BMJ 2002;325:430-2.

11. Durbach N. Bodily matters: the anti-vaccination movement in England, 1853-1907. Durham (NC): Duke University Press; 2005.

12. Keelan J, Risk, efficacy and viral attenuation in debates over smallpox vaccination in Montreal, 1870. In: Crafting immunity: working histories of clinical immunology. Kroker K, Mazumdar MH, Keelan JE, editors. Burlington (VT): Ashgate; 2008:29-41.
13. Farley $\mathrm{M}$, Keating $\mathrm{P}$, Keen $\mathrm{O}$, et al. Vaccination in Montreal in the second half of the 19th century: practices, obstacles and resistance [chapter in French]. In: Sciences \& médecine au Québec: perspectives sociohistoriques. Québec: Institut québécois de recherche sur la culture; 1987:87-127.

14. Rutty CJ. Book review: Heather MacDougall, Activists and Advocates: Toronto's Health Department, 1883-1983, Toronto and Oxford, Dundurn Press, 1990. Pp 297, endnotes, selected bibliography, 80 illustrations. ISBN 1-55002-072-2, \$29.95 (cloth). Scientia Canadensis 1992;16:109-12.

15. Bricker D. Many Canadians aren't in a hurry to receive COVID-19 vaccine. https://www.ipsos. com/en-ca/news-polls/many-canadians-arent-in -a-hurry-to-receive-covid-19-vaccine. Ipsos 2020 Nov. 6 (accessed 2020 Dec. 10).

This article has been peer reviewed.

Competing interests: None declared.

Content licence: This is an Open Access article distributed in accordance with the terms of the Creative Commons Attribution (CC BY-NC-ND 4.0) licence, which permits use, distribution and reproduction in any medium, provided that the original publication is properly cited, the use is noncommercial (i.e., research or educational use), and no modifications or adaptations are made. See: https://creativecommons. org/licenses/by-nc-nd/4.0/ 